BIOMEDICAL AND BIOSOCIAL ANTHROPOLOGY
$\begin{gathered}\text { Official Journal of the International Academy } \\ \text { of Integrative Anthropology } \\ \text { journal homepage: http://bba-journal.com }\end{gathered}$

\title{
Regression models of individual cephalometric indicators used in the method of R. M. Ricketts
}

\section{Chernysh A. $V$.}

National Pirogov Memorial Medical University, Vinnytsya, Ukraine

\section{ARTICLE INFO}

Received: 9 July, 2018

Accepted: 23 August, 2018

UDC: $616-073.75: 616.314 .26-053.81$

\section{CORRESPONDING AUTHOR}

e-mail: andre.chernysh@gmail.com Chernysh A. V.
It is proved that in the analysis of lateral teleroentgenograms according to different methods distances and angles have their normative indices which differ for persons of different ethnic, gender and age belongings. Therefore, for a full use in the orthodontics R.M. Ricketts method, similar studies are needed in Ukraine. The purpose of the work - in boys and girls with normal occlusion close to the orthognathic bite and harmonious face construct and analyze the regression models of teleroentgenographic indicators used in the method of R. M. Ricketts. Primary lateral teleroentgenograms of 38 young men (aged 17-21 years) and 55 young women (aged from 16 to 20 years) with normal occlusion close to orthognathic bite and harmonic face, obtained from the Veraviewepocs 3D device, Morita (Japan), taken from the bank data of research center of National Pirogov Memorial Medical University, Vinnytsya. Cephalometric measurements were performed according to the recommendations of $R$. M. Ricketts. All indicators were divided into three groups: 1 - metric characteristics of the skull, which usually do not change during surgical and orthodontic treatment; 2 - tooth-jaw indicators, the definition of which most often guided by performing orthodontic manipulations of patients in children and adolescents, as well as those with already formed bone skeleton when orthodontic surgery can change the width, length, angles and position of the bones of the upper and lower jaws; 3 - indicators that characterize the position of each individual tooth relative to each other, to the bony cranial structures and face profile. The regression models of individual teleroentgenographic indicators used in the R.M. Ricketts methodology are constructed using the "Statistica 6.0" licensing package. Constructed all 2 reliable models of the indicators included in the second group (distance Go-CF and Xi-Pm), depending on the indicators of the first group (in young men $R^{2}=0.884$ and 0.928 , and in young women - 0.735 and 0.719 ); as well as in young men, 7 out of 8 possible reliable models $\left(R^{2}=0.568\right.$ to 0.887$)$ of the indicators included in the third group (the magnitude of the distances 6u-6l, Overjet, Overbite, 6uPTV, 1I-APog, 1u-APog and Xi-OcP) depending on the indicators of the first and second groups; and only 5 models for young women (6u-PTV, 1l-APog, $1 \mathrm{u}-A P \circ g$ and XiOcP distances, and the magnitude of the Max1-APog angle). In the analysis of entering into the regression models of the relevant predictors, it was found that in young men, among the teleroentgenographic indicators of the first group included in the two models of the second group, is the distance P-PTV, and in young women the front length of the base of the skull N-CC and the back of the skull base Ar- Pt It was also found that among young men among the teleroentgenographic indicators of the first and second groups, which were included in the models of the third group, the most frequent is the value of the distance B-Pog (11.1\%); while in young women - distance B-Pog (15.6\%) and an angle $D C-X i-P M(9.4 \%)$.

Keywords: regression analysis, cephalometry, R. M. Ricketts analysis, young men and women, orthognathic bite.

\section{Introduction}

The question of forming a harmonious smile is not of dentistry has undergone various stages of development, new for orthodontics. During its development, this section achieving a significant progress in the early 20th century. 
The development and introduction into practice of new instrumental methods of patient examination (namely, teleroentgenography), combined with the development of anthropology (namely, craniology), allowed in the combination to create a unique in its kind - a cephalometric analysis, which is a reliable tool in the work of modern orthodontics [33]. Moreover, the results of this study have found application in other areas of medicine, in particular in forensic medicine [30].

It should be noted that at the moment there are more than 100 methods of cephalometric analysis of lateral teleroentgenograms. Widespread methods were achieved by S. C. Steiner, Viken Sassouni, C. H. Tweed, Witwatersrand, E. P. Harvold, Joseph Jarabak, C. J. Burstone [1-5].

Widely used in practical use is the analysis proposed in 1961 by Ricketts R. M. By the way, according to the author himself, the technique was created under the inspiration (and taking into account the drawbacks) of the similar work of $W$. Downs. The various points and planes form the following major pathways in this technique, such as Li-EL, ILi-/A-Pog, Ms-PtV, Li-A-Pog, Convexity and such main angles as ML/FH, Facial Angle, Facial Axis [20, 32]. Accordingly, each distance and angles have their own normative indexes, which according to the authors as a whole form a harmonious tooth-jaw system. However, as has already been proven in the works on other methods of cephalometric analysis of lateral teleroentgenograms, these indices are different for persons of different ethnic, gender and age affiliations [7, 10, 11, 15].

At present, numerous studies are carried out in different parts of the world, confirming a similar statement for the method of R. M. Ricketts [19, 24, 26-28, 31, 34, 35].

The purpose of the work - in young men and women with normal occlusion close to orthognathic bite and harmonious face to construct and analyze the regression models of teleroentgenographic indicators used in the method of R. M. Ricketts.

\section{Materials and methods}

Primary lateral teleroentgenograms of 38 young men (aged 17-21 years) and 55 young women (aged from 16 to 20 years) with normal occlusion close to orthognathic bite and harmonic face, obtained from the Veraviewepocs 3D device, Morita (Japan), taken from the bank data of research center of National Pirogov Memorial Medical University, Vinnytsya.

Analysis of lateral teleroentgenograms by methods of $\mathrm{R}$. M. Ricketts, C. J. Burstone and E. P. Harvold in detail described by us in previous studies $[12,13,18]$.

All indicators of these techniques were divided into three groups: the first group - metric characteristics of the skull, which usually do not change during surgical and orthodontic treatment, determine the inclination, anterior-posterior or vertical position of the gnatic structures (upper and lower jaws, occlusal plane, individual teeth); the second group -

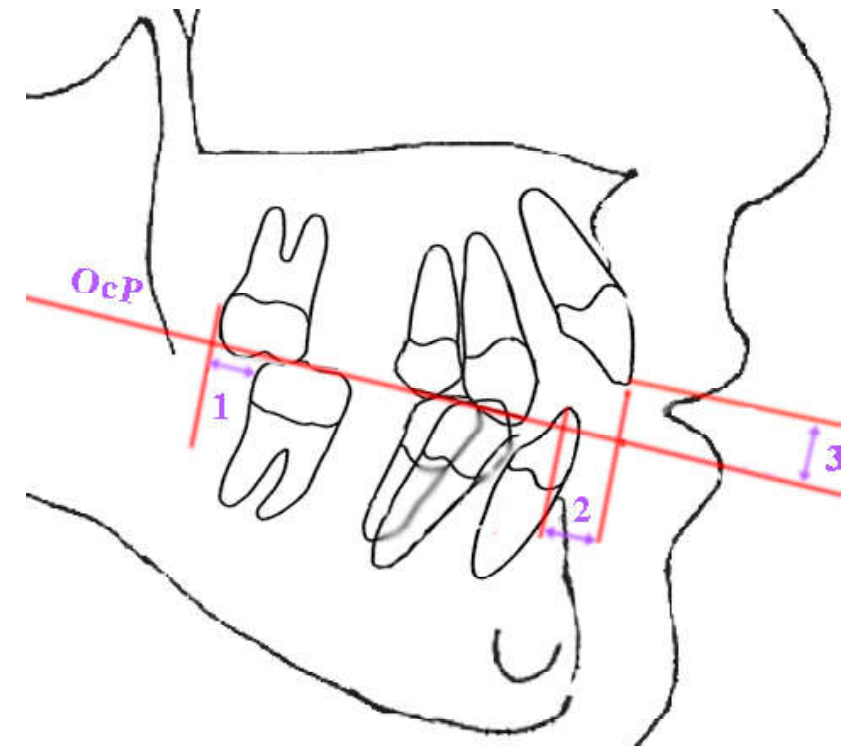

Fig. 1. 1. 6u-6I - the distance between the rear surfaces of the upper and lower first molar, the distance from the point P6U to the point $\mathrm{P} 6 \mathrm{~L}$ on the closing plane $(\mathrm{mm}) ; 2$. Overjet - the distance between the cutting edges of the upper and lower median cutters, the distance from the Is1 u point to the Is $1 \mathrm{~L}$ point on the closing plane $(\mathrm{mm}) ; 3$. Overbite - the distance between the cutting edges of the upper and lower median cutters, the distance from the point of Is $1 \mathrm{u}$ to the Is $1 \mathrm{~L}$ point on the perpendicular to the closing plane (mm).

tooth-jaw indicators, the definition of which most often guided by performing orthodontic manipulations of patients in children and adolescents age, as well as people with already formed bone skeleton when orthodontic surgery allows you to change the width, length, angles and position of the bones of the upper and lower jaw; the third group - indicators that characterize the position of each individual tooth relative to each other, to the bony cranial structures and face profile [21].

According to the cephalometric method R. M. Ricketts $[25,32]$, we simulated the following parameters of the second group, depending on the indicators of the first group (Fig. 1, Fig. 2): Go-CF - posterior face height ( $\mathrm{mm}), \mathbf{X i}-\mathbf{P m}$ - distance from points $\underline{X i}$ to the point $\underline{P m}(\mathrm{~mm})$. Depending on the indicators of the first and second groups, the following indices by R. M. Ricketts included in the third group were determined: 6u-6I - the distance between the posterior surfaces of the upper and lower first molar ( $\mathrm{mm})$; Overjet - the distance between the cutting edges of the upper and lower median cutters ( $\mathrm{mm}$ ); Overbite - the distance between the cutting edges of the upper and lower median cutters (mm); 6u-PTV - arrow position of the first molar (mm); 1I-APog - distance from Is1L to A-Pog line (mm); 1u-APog - distance from Is1u to A-Pog line (mm); Max1-APog - the angle formed by the lines Is1u-Ap1u and A-Pog $\left({ }^{\circ}\right)$; Xi-OcP - distance between the closure plane OcpD and the center of the branch of the mandible $\underline{X i}(\mathrm{~mm})$.

Regression models teleroentgenographic individual 


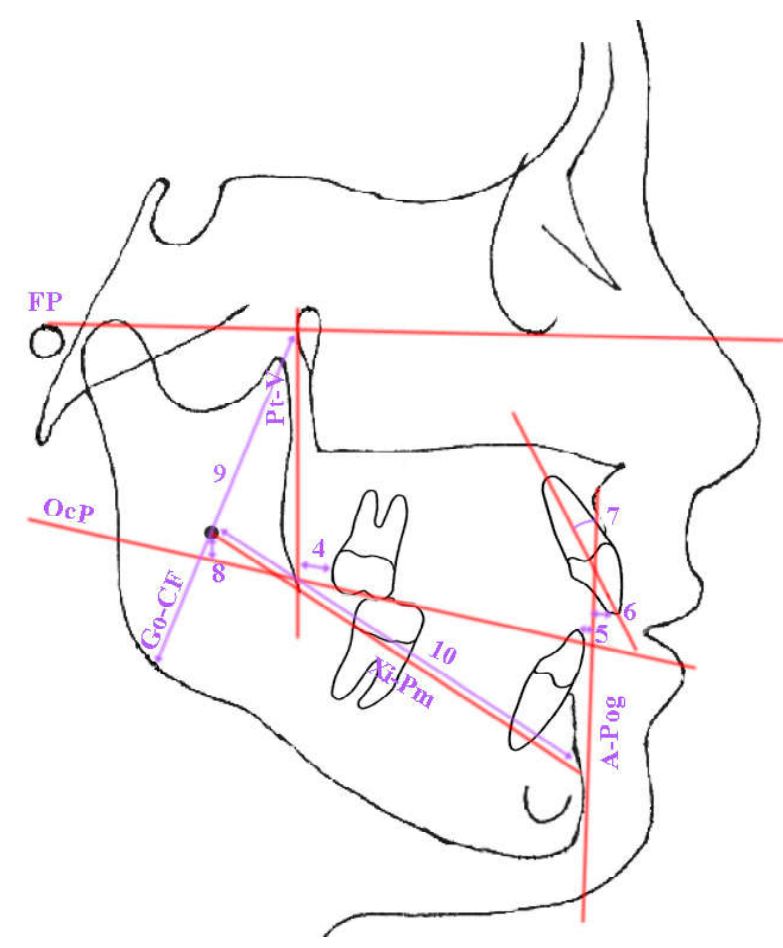

Fig. 2. 4. 6u-PTV - arrow position of the first molar, distance from point $\mathrm{P6u}$ to perpendicular to $\mathrm{Po-Or}$ (Frankfurt area) conducted from point $\mathrm{Pt}(\mathrm{mm}) ;$ 5. 1I-APog - distance from $I s 1 \mathrm{~L}$ to $\mathrm{A}-\mathrm{Pog}$ line (mm); 6. 1u-APog - distance from Is1u to A-Pog line (mm); 7. Max1-APog - the angle formed by the lines Is1u-Ap1u and A-Pog $\left({ }^{\circ}\right)$; 8. Xi-OcP - distance between the closure plane Ocp and the center of the branch of the mandible $\underline{X i}(\mathrm{~mm}) ; 9$. Go-CF - posterior face height, distance from point Go to point $\underline{\mathrm{CF}}(\mathrm{mm}) ; 10$. Xi-Pm distance from point Xi to point $\underline{P m}(\mathrm{~mm})$.

indicators used in the method of R. M. Ricketts built in the license package "Statistica 6,0".

\section{Results}

The results of modeling teleroentgenographic indices by the method of R. M. Ricketts, which are included in the second group, depending on the indicators of the first group, have the form of the following linear equations.

For young men:

$\underline{\text { Go-CF }}=3.425-1.095 \times$ P-PTV $+0.379 \times \mathrm{N}-\mathrm{CC}\left(\mathrm{R}^{2}=0.884\right.$; $F_{(2.35)}=133.6 ; p<0.001$; Error of estimate $\left.=3.751\right)$;

Xi-Pm = -3.649+0.807 x Pt-N - 0.802 x P-PTV $\left(R^{2}=0.928\right.$; $F_{(2.35)}=226.6 ; p<0.001$; Error of estimate=3.292);

where, and hereafter, $\mathrm{R}^{2}$ - coefficient of determination; $\mathrm{F}_{(!, ! !)}=$!!,!! - critical (!,!!) and got (!!,!!) value of Fisher's criterion; St. Error of estimate - standard error of the standardized regression coefficient; $\mathrm{P}-\mathrm{PTV}$ is the distance from point $\underline{\mathrm{Po}}$ to point $\underline{P t}$, parallel to the Frankfurt area $(\mathrm{mm}) ; \mathrm{N}-\mathrm{CC}$ - the front length of the base of the skull, the distance from point $\underline{N}$ to the point of the $\underline{\mathrm{CC}}(\mathrm{mm})$; Pt-N - the front part of the base of the skull, the distance from the point $\underline{P t}$ to the point $\underline{N}$, defines the length of the front of the skull base $(\mathrm{mm})$.

For young women:

Go-CF $=-15.88-0.585 x$ P-PTV $+0.637 \times N-C C+0.717 x$
Ar-Pt $\quad\left(R^{2}=0.735 ; \quad F_{(3.51)}=47.22 ; p<0.001 ;\right.$ Error of estimate $=4.089$ );

Xi_PM $=-0.720+0.781 \times \mathrm{N}-\mathrm{CC}+0.551 \times \mathrm{Ar}-\mathrm{Pt}+0.279 \mathrm{x}$ POr-NBa $\left(R^{2}=0.719 ; F_{(3.51)}=43.56 ; p<0.001\right.$; Error of estimate=3.352);

where and in the future, Ar-Pt is the back of the base of the skull, the distance from the point $\underline{\mathrm{Ar}}$ to the point $\underline{\mathrm{Pt}}$, determines the length of the back of the skull base, parallel to the horizontal line behind by Burstone (HR Line - the line is drawn through the point $\underline{\mathrm{N}}$ and $7^{\circ}$ higher than $\underline{\mathrm{S}-\mathrm{N}}$ line) $(\mathrm{mm})$; POr-NBa - angle of the cranial tilt (deflection), the angle formed by the lines $\underline{\mathrm{Po}-\mathrm{Or}}$ and $\mathrm{Ba}-\mathrm{N}\left({ }^{\circ}\right)$.

The results of modeling teleroentgenographic indices by the method of R.M. Ricketts, which are included in the third group, depending on the indicators of the first and second groups, have the form of the following linear equations.

For young men:

6u-6I $=0.641-0.310 \times$ Max-Mand $+0.737 \times$ B-Pog -0.063 x N-Pog - 0.208 x PNS-N + 0.200 x Ar-Go $\left(R^{2}=0.604\right.$; $F_{(5.32)}=9.75 ; p<0.001$; Error of estimate=1.122);

Overjet $=-0.772+0.051 \times$ ANS-Cond $+0.138 \times \mathrm{N}-\mathrm{A}-\mathrm{Pog}$ $-0.100 \times N-A N S-P o g\left(R^{2}=0.619 ; F_{(3.34)}=18.40 ; p<0.001\right.$; Error of estimate $=0.563$;

Overbite $=4.188-0.204 \times$ Pog-Cond $+0.121 \times \mathrm{N}-\mathrm{ANS}-$ $0.218 \times$ N-ANS-Pog $+0.195 \times$ ANS-Cond $+1.039 \times$ N-A-Pog - $1.831 \times A-N P o g\left(R^{2}=0.678 ; F_{(6.31)}=10.87 ; p<0.001\right.$; Error of estimate $=0.794)$;

6u-PTV $=-31.40+0.703 \times$ POr-CFXi $-0.503 \times$ N-CF-A + $0.224 \times \mathrm{Xi}-\mathrm{Pm}+0.203 \times \mathrm{DC}-\mathrm{Xi}-\mathrm{Pm}+0.180 \times \mathrm{MP}-\mathrm{HP}$ $\left(R^{2}=0.887 ; F_{(5.32)}=50.28 ; p<0.001 ;\right.$ Error of estimate=1.746);

1I-APog $=0.049-0.121 \times$ Go-Pog $+0.238 \times$ Pog-Cond $0.126 \times$ POr-NBa $-0.188 \times$ N-CC $-0.490 \times$ B-Pog $+0.079 \times$ MP-HP $\quad\left(R^{2}=0.576 ; \quad F_{(6.31)}=7.02 ; p<0.001\right.$; Error of estimate $=1.025)$;

1u-APog = $10.57-0.296 \times$ P-PTV $-0.661 \times$ B-Pog -0.183 $x$ MeGo-NPog $\left(R^{2}=0.568 ; F_{(3.34)}=14.90 ; p<0.001\right.$; Error of estimate $=1.207)$;

$\mathrm{Xi}-\mathrm{OcP}=9.218-0.579 \times \mathrm{NPog}-\mathrm{POr}-0.298 \times \mathrm{PNS}-\mathrm{N}-$ $1.325 \times A-B+1.365 \times A-N P o g-0.208 \times$ POr-ANSPNS + 1.209 $x$ B-Pog + 0.588 x MeGo-NPog + $0.163 \times$ DC-Xi-PM $\left(R^{2}=0.845\right.$; $F_{(8.29)}=19.72 ; p<0.001$; Error of estimate $\left.=1.565\right)$;

here and thereafter, $A-B$ - distance from point $\underline{A}$ to point $\underline{B}$ on the closure plane (apOcP-ppOcP) (mm); A-NPog convexity, distance from point $\underline{A}$ to line $\underline{N}-\mathrm{Pog}(\mathrm{mm})$; ANSCond (also found as TM-ANS) - length of the upper jaw, distance from point TM to the point ANS (mm); Ar-Go - the length of the branch of the lower jaw, the distance from the

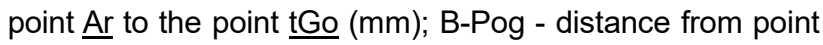
Pog to point $\underline{B}$, parallel to mandibular plane $(\mathrm{mm})$; DC-Xi$\overline{P M}$ - the angle formed by the lines $\underline{\mathrm{DC}-\mathrm{Xi}}$ and $\underline{\mathrm{Xi}-\mathrm{Pm}}\left({ }^{\circ}\right)$; GoPog - the length of the base of the mandible, the distance from the point Pog to the point $\underline{\mathrm{tGo}}(\mathrm{mm})$; Max-Mand - interjaw difference, difference between distances TM-ANS and TMPGN (mm); MeGo-NPog - face cone, the angle formed by the lines $\underline{\mathrm{Me}-\mathrm{Go}}$ and $\underline{\mathrm{N}-\mathrm{Pog}}\left({ }^{\circ}\right)$; MP-HP - the mandibular 
angle to the horizontal line by Burstone, formed by the mandibular plane Mand. Plane and $\underline{\mathrm{HR}}$ line $\left({ }^{\circ}\right)$; N-ANS - the front upper face height determines the length of the upper part of the front face height, the distance from the point $\underline{N}$ to the point ANS $(\mathrm{mm})$; N-ANS-Pog - angle of the convex profile formed by the lines $\underline{N-A N S}$ and ANS-Pog $\left({ }^{\circ}\right)$; N-A-Pog - the angle of the skeletal profile, determines the convexity of the face, formed by the lines $\mathrm{N}-\mathrm{A}$ and $\mathrm{A}-\mathrm{Pog}\left({ }^{\circ}\right) ; \mathrm{N}-\mathrm{CC}$ - the front length of the base of the skull, the distance from point $\underline{N}$ to the point of the $\underline{\mathrm{CC}}(\mathrm{mm})$; N-CF-A - angle of the upper jaw height, angle formed by the lines $\underline{\mathrm{N}-\mathrm{CF}}$ and $\mathrm{CF}-\mathrm{A}\left({ }^{\circ}\right)$; N-Pog - distance that characterizes the position of the chin, the distance from the perpendicular to the horizontal line by

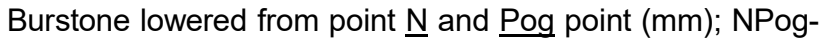
$\mathrm{POr}$ - depth of face, angle between $\mathrm{N}$-Pog faceplate and $\mathrm{PO}-$ Or $\left({ }^{\circ}\right)$ Frankfurt area; PNS-N - the posterior upper face height determines the length of the upper part of the posterior face height from the PNS point to the horizontal line by Burstone $(\mathrm{mm})$; Pog-Cond (also found as TM-PGN) - length of the lower jaw, distance from point $\underline{\mathrm{TM}}$ to the point $\underline{\mathrm{PGN}}(\mathrm{mm})$; POr-CFXi - the angle formed by the lines of Po-CF and CF-Xi, characterizes the position of the branch of the mandible $\left(^{\circ}\right)$; POr-ANSPNS (also known as POr-SpP) - the angle formed by the lines Po-Or and ANS-PNS $\left({ }^{\circ}\right)$; Xi-Pm - distance from the point $\underline{X i}$ to the point $\underline{P m}(\mathrm{~mm})$.

For young women:

6u-PTV $=-50.79+0.527 \times$ POr-CFXi $+0.361 \times \mathrm{Xi}-\mathrm{Pm}+$ 0.224 x POr-NBa - 0.438 x B-Pog - 0.107 x Go-CF + 0.179 x PNS-ANS $\left(R^{2}=0.880 ; F_{(6.48)}=58.75 ; p<0.001\right.$; Error of estimate=1.329);

1I-APog $=6.479+0.251 \times$ ANS-Xi-PM $-0.949 \times$ B-Pog $0.279 \times$ MeGo-NPog $+0.138 \times$ N-CC + $0.076 \times$ DC-Xi-PM $\left(R^{2}=0.515 ; F(5.49)=10.40 ; p<0.001 ;\right.$ Error of estimate=1.394);

1u-APog $=-22.00+0.237 \times$ ANS-Xi-PM $-0.793 \times$ B-Pog + $0.185 \times$ POr-NA + $0.165 \times$ Pt-N - $0.157 \times$ Ar-Go + $0.170 \times$ MaxMand $\left(R^{2}=0.530 ; \quad F_{(6.48)}=9.03 ; p<0.001\right.$; Error of estimate=1.437);

$\mathbf{X i - O c P}=-19.54-1.405 \times$ A-B + $0.619 \times$ MeGo-NPog + $0.732 \times$ N-A-Pog + $1.106 \times$ B-Pog $-0.370 \times$ POr-NA + $0.172 \times$ DC-Xi-PM - $0.096 \times$ Xi-Pm $\left(R^{2}=0.867 ; F_{(7.47)}=43.78 ; p<0.001\right.$; Error of estimate $=1.306)$;

Max1-APog $=13.04+0.615 \times$ N-A-Pog $-0.609 \times$ Go-CF $0.460 \times$ N-ANS-Pog - $1.008 \times$ B-Pog $+0.474 \times$ Pog-Cond $1.341 \times \mathrm{N}-\mathrm{Pog}+0.283 \times \mathrm{DC}-\mathrm{Xi}-\mathrm{PM}+1.326 \times \mathrm{N}-\mathrm{B}\left(\mathrm{R}^{2}=0.611\right.$; $F_{(8.46)}=9.02 ; p<0.001$; Error of estimate=3.367);

where, ANS-Xi-PM - angle of the lower height of the face, the angle formed by the lines ANS-Xi and Xi-Pm $\left({ }^{\circ}\right)$; Go-CF posterior face height, distance from point $\underline{\mathrm{Go}}$ to point $\underline{\mathrm{CF}}$ $(\mathrm{mm}) ; \mathrm{N}-\mathrm{B}$ - the distance that characterizes the position of the lower jaw (Mandibular Position), the distance from the perpendicular to the horizontal line by Burston lowered from the point $\underline{N}$, and point $\underline{B}(\mathrm{~mm})$; PNS-ANS (also found as ANS-PNS) - length of maxilla (Maxillary Length), distance from the ANS to the PNS point parallel to the horizontal line by Burston (mm); POr-NA is the angle of the depth of the upper jaw, the angle formed by the lines $\underline{\mathrm{Po}-\mathrm{Or}}$ and $\underline{\mathrm{N}-\mathrm{A}}\left(^{\circ}\right)$.

\section{Discussion}

R. Al-Azemi and J. Artun [6] conducted in 2011 a study of 81 boys and 78 girls ethnic Kuwaiti people aged from 13 to 14 with an ideal smile using the Ricketts method to determine normative indices for the region and identify sexual manifestations dimorphism. The obtained data were compared with the results of studies from other countries (Australia and Turkey). The higher values of dental indices compared with the data of Ricketts are lower than those obtained from Turkey; compared to Australian teenagers higher indices of mandibular arc and lower figures of the maxillary arc. When compared with skeletal indices, all sizes were larger compared to the Ricketts data, but they are the same as those obtained in the study of Australian and Turkish teenagers. No manifestations of sexual dimorphism were found.

E. J. Bae and colleagues [8] examined 18 male and 18 female representatives aged from 9 to 19 years to determine Ricketts normative indicators for the population of South Korea. The obtained data were compared with the results of Ricketts and the values obtained by Japanese scientists in a similar study. Significant sexual differences of the indicators at the age of 9 years were revealed. Girls had higher levels of horizontal overlapping and convex of incisors, while boys had higher B1-A-RO intervals, interincisal angle and inclination of B1-A-RO. It was also found that for the Koreans, sexual dimorphism of the molar ratio is not characteristic.

R. H. L. Belluzzo et al. [9] determined the correlations between the Ricketts transversal and vertical indices for Brazilian adolescents. For the study, 25 girls and 20 boys aged from 7 to 13 years were selected that had a physiological bite and no history of any interference with the tooth-jaw system. Strong positive correlations (more than 0.800 ) between OVD and TVD, average power (from 0.500 to 0.799 ) for MxTD and FTD, MdTD and FTD, MxTD and MdTD, TVD and MdTD indicators were found.

A group of scientists found the features of the Ricketts methodology for the Cuban population of adolescence age [14]. 1675 children from different regions of Cuba aged 9 years were examined. Of these, 163 were selected that had a physiological bite. It was found that only three indices obtained in the study were identical to those of the Ricketts, namely, the front axis, the depth of the face, and the depth of the upper jaw. All other indicators had significant differences.

I. E. Perez, A. K. Chavez and D. Ponce [29] compared Ricketts' normative indicators with data from 318 individuals aged from 9 to 18 years, Spanish-speaking Peruvians, and similar studies from around the world. Significant discrepancies in the indicator of LMM have been detected - Peruvians have higher rates than Ricketts data, but similar to those obtained in studies in Turkey, Palestine and China. While the values of AG-GA and ZA-AZ were lower than in the aforementioned studies. Significant manifestations of sexual dimorphism (for 7 of 12 transversal variables) were also revealed.

Unfortunately, the work of domestic scientists on this subject is rather small [13, 16, 17, 22, 23]. This greatly 
complicates the use of techniques of cephalometric analysis of lateral teleroentgenograms and in particular the Ricketts method, which in turn impairs the provision of orthodontic care to the Ukrainian population. Only a comprehensive study that can take into account such indicators as age, gender, ethnicity, regional identity of a person, etc. will allow to create a complete base of normative indicators, and only then it will become possible to fully use the method of Ricketts.

In young men and young women with normal occlusion close to orthognathic bite and harmonious face we have constructed all 2 possible reliable models (Go-CF and Xi$\mathrm{Pm}$ distances) of teleroentgenographic indices by the method of R. M. Ricketts, which were included in the second group, depending on the indicators of the first group. It is established that in young men the determination coefficient in models is much higher than in young women (in young men R2 $=0.884$ and 0.928 , and in young women -0.735 and 0.719 ), which coincides with the results of simulation obtained by the method of C. J. Burstone [21]. In both models, in young men include the distance P-PTV, and in young women the front length of the base of the skull N-CC and the back of the skull base Ar-Pt, which determines the length of the back of the skull base. Also, only in young men, models of teleroentgenographic indices using the R. M. Ricketts technique included in the second group, depending on the indicators of the first group, include the anterior part of the base of the skull Pt-N, which determines the length of the anterior part of the skull base, and only in young women, the angle of the cranial tilt POr- NBa.

In the modeling of teleroentgenographic indices that were included in the third group according to the method R. M. Ricketts, depending on the indicators of the first and second groups in young men, 7 of 8 possible reliable regression models with a determination coefficient greater than 0.5 $\left(R^{2}=\right.$ from 0.568 to 0.887$)$ were constructed and in young women - only 5 models ( $R^{2}=$ from 0.515 to 0.880$)$. Both in young men and women, the built-up regression equations most often include the value of the distance B-Pog $(11.1 \%$ in young men and $15.6 \%$ in young women). In addition, the regression equations for young men most often include the value of the distance A-NPog, the length of the upper jaw ANS-Cond, the posterior upper face height PNS-N, the length

\section{References}

[1]Al Sabbagh, R. (2014). Syrian norms of McNamara cephalometric analysis. International Arab Journal of Dentistry, 3(5), 95101.

[2] Al Taki, A., Yaqoub, S., \& Hassan, M. (2018). Legan-burstone soft tissue profile values in a Circassian adult sample. Journal of orthodontic science, 7, 18. doi: 10.4103/jos.JOS_27_18

[3] Alam, M. K., Basri, R., Purmal, K., Sikder, M. A., Saifuddin, M., \& lida, J. (2013). Cephalometric norms in Bangladeshi adults using Harvold's analysis. International Medical Journal, 20(1), 92-94.

[4]Alam, M. K., Basri, R., Purmal, K., Sikder, M. A., Saifuddin, M., \& lida, J. (2013). Cephalometric norm study in a Bangladeshi population using McNamara analysis. International Medical Journal, 20(1), 84-86. of the lower jaw Pog-Cond, and the magnitude of the angles DC-Xi-PM, MeGo- NPog, MP-HP, N-ANS-Pog and NA-Pog (by $5.6 \%$ ); and in young women the magnitude of the angle of DC-Xi-PM (9.4\%), as well as the posterior face height, the distance Xi-Pm and the angles ANS-Xi-PM, MeGo-NPog, NAPog and POr-NA (by 6.25\%). Also, only in young men, the models of teleroentgenographic indicators included in the third group according to R. M. Ricketts method, depending on the indicators of the first and second groups, include the magnitude of the distances P-PTV, Go-Pog and N-ANS and the magnitude of the angles of N-CF-A, NPog-POr and POrANSPNS (by $2.8 \%$ ); only in young women - the magnitude of distances Pt-N, N-B and PNS-ANS (by $3.1 \%$ ).

Again, it should be noted that only a similar approach to diagnosis and treatment meets the contemporary challenges of medicine, when a physician needs to have as much as possible an individual, chosen for each patient a method of providing medical care and refuse an intuitive search algorithm for treatment.

\section{Conclusions}

1. In young men and women with normal occlusion close to the orthognathic bite, by two possible models of teleroentgenographic indices using the R. M. Ricketts method were included in the second group, depending on the indicators of the first group, respectively, $R^{2}=0.884$ and 0.928 in young men and 0.735 and 0.719 in young women; as well as in young men, 7 of the 8 possible models included in the third group, depending on the indicators of the first and second groups with $R^{2}$ from 0.568 to 0.887 , and in young women - only 5 models with $\mathrm{R}^{2}$ from 0.515 to 0.880 .

2. In young men, in both models, teleroentgenographic indices of the first group included in the models of the second group according to R.M. Ricketts method are the distance PPTV, and in young women the anterior length of the base of the skull N-CC and the posterior part of the skull base Ar-Pt.

3 . In young men, among the teleroentgenographic indices of the first and second groups that were included in the models of the third group by the method of R. M. Ricketts most often includes the value of the distance B-Pog (11.1\%), and in young women - the value of the distance B-Pog $(15.6 \%)$ and the magnitude of the angle DC-Xi-PM (9.4\%).

[5]Alam, M. K., Basri, R., Purmal, K., Sikder, M. A., Saifuddin, M., \& lida, J. (2013). Craniofacial morphology of Bangladeshi adult using Tweed's and Wit's analysis. International Medical Journal, 20(2), 197-200.

[6] Al-Azemi, R., \& Artun, J. (2011). Posteroanterior cephalometric norms for an adolescent Kuwaiti population. The European Journal of Orthodontics, 34(3), 312-317. doi: 10.1093/ejo/ cjr007

[7]Atit, M. B., Deshmukh, S. V., Rahalkar, J., Subramanian, V., Naik, C., \& Darda, M. (2013). Mean values of Steiner, Tweed, Ricketts and McNamara analysis in Maratha ethnic population: $\mathrm{A}$ cephalometric study. APOS Trends in Orthodontics, 3(5), 137151. doi: 10.4103/2321-1407.119095

[8] Bae, E. J., Kwon, H. J., \& Kwon, O. W. (2014). Changes in 
longitudinal craniofacial growth in subjects with normal occlusions using the Ricketts analysis. The Korean Journal of Orthodontics, 44(2), 77-87. doi: 10.4041/kjod.2014.44.2.77

[9] Belluzzo, R. H. L., Faltin Jr, K., Ortolani, C., \& Chelotti, A. (2013). Correlation between transverse and vertical measurements in Brazilian growing patients, evaluated by Ricketts-Faltin frontal analysis. Dental press journal of orthodontics, 18(1), 50-54. doi: http://dx.doi.org/10.1590/S217694512013000100013

[10] Cardoso, R., Ajzen, S., Andriolo, A. R., Oliveira, J. X. D., \& Andriolo, A. (2012). Analysis of the cephalometric pattern of Brazilian achondroplastic adult subjects. Dental Press Journal of Orthodontics, 17(6), 118-129. doi: http://dx.doi.org/10.1590/ S2176-94512012000600023

[11] Celebi, A. A., Tan, E., Gelgor, I. E., Colak, T., \& Ayyildiz, E. (2013). Comparison of soft tissue cephalometric norms between Turkish and European-American adults. The scientific world journal, 2013. doi: 10.1155/2013/806203

[12] Chernysh, A. V. (2018). Cephalometric studies of Ukrainian young men and women with orthognathic bite by the method of E. P. Harvold. Reports of Morphology, 23(2), 38-43. https:/ /doi.org/10.31393/morphology-jornal-2018-24(2)-06

[13] Chernysh, A. V., Gunas, I. V., Gavryluk, A. O., Dmytrenko, S. V., Serebrennikova, O. A., Kyrychenko, Yu. V., \& Balynska, M. V. (2018). Cephalometric studies of ukrainian boys and girls with orthognathic bite by the method of R. M. Ricketts. World of Medicine and Biology, 14(64), 88-93. doi: https://doi.org/ 10.26724/2079-8334-2018-2-64-88-93

[14] Conde Suarez, H. F., Vila Morales, D., Puig Ravinal, L. E., Garmas Castillo, Y., \& Valentin Gonzalez, F. (2018). Confidence interval for the standards of the Ricketts? summarized cephalogram in Cuban children. Revista Medica Electronica, 40(1), 35-47. Disponible en: http://www.revmedicaelectronica.sld.cu/ index.php/rme/article/view/2256/3688

[15] de Lima Lucas, B., Junior, R. B., Goncalves, L. C., Gaviao, M. B. D., \& Gomes, V. L. (2012). Research and clinical applications of facial analysis in dentistry. Oral Health Care Prosthodontics, Periodontology, Biology, Research and Systemic Conditions. ISBN: 978-953-51-0040-9, InTech, Available from: http://www.intechopen.com/books/oralhealth-careprosthodontics-periodontology-biology-researchand-systemic-conditions/research-and-clinical-applicationsoffacial-analysis-in-dentistry

[16] Dmitriev, M. O. (2016). Definition of normative cephalometric parameters by Steiner method for ukrainian young men and women. World of Medicine and Biology, 3(57), 28-32.

[17] Dmitriev, M. O., Chugu, T. V., Gerasymchuk, V. V., \& Cherkasova, O. V. (2017). Determination of craniometric and gnatometric indicators by A. M. Schvartz metod for Ukrainian boys and girls. Biomedical and Biosocial Anthropology, 29, 53-58.

[18] Dmitriev, M., Chernysh, A., \& Chugu, T. (2018). Cephalometric studies of Ukrainian boys and girls with physiological bite by the method of Charles J. Burstone. Biomedical and Biosocial Anthropology, 30, 62-67. doi: https://doi.org/10.31393/bba302018-09

[19] Gonzalez, M. B., Caruso, J. M., Sugiyama, R. M., \& Schlenker, W. L. (2013). Establishing cephalometric norms for a Mexican population using Ricketts, Steiner, Tweed and Arnett analyses. APOS Trends in Orthodontics, 3(6), 171-177. doi: 10.4103/ 2321-1407.121437

[20] Grummons, D. (2015). Smile because of Dr Robert Murray Ricketts. American Journal of Orthodontics and Dentofacial Orthopedics, 148(3), 368-373. doi: https://doi.org/10.1016/ j.ajodo.2015.04.018

[21] Gunas, I. V., Chernysh, A. V., Cherkasov, V. G., Cherkasova, O. V. (2018). Modeling by using regression analysis of teleroentgenographic individual indicators used in the method of Charles J. Burstone. Biomedical and Biosocial Anthropology, 31, 59-65. doi: https://doi.org/10.31393/bba31-2018-08

[22] Gunas, I. V, Dmitriev, M. O, Prokopenko, S. V., ShinkarukDykovytska, M. M., \& Yeroshenko, G.A. (2017). Determination of regulatory cephalometric parameters according to Charles $\mathrm{H}$. Tweed International Foundation analysis for Ukrainian boys and girls. World of Medicine and Biology, 4(62), 27-31. doi: https://doi.org/10.26724/2079-8334-2018-2-64-88-93

[23] Gunas, I. V, Dmitriev, M. O, Tikholaz, V. O., ShinkarukDykovytska, M. M., Pastukhova, V. A., Melnik, M. P., \& Rudiy, Yu. I. (2018). Determination of normal cephalometric parameters by J. McNamara method for Ukrainian boys and girls. World of Medicine and Biology, 1(63), 19-22. doi: https:/ /doi.org/10.26724/2079-8334-2018-1-63-19-22

[24] Ikenna Isiekwe, G., Olatokunbo da Costa, O., \& Chukwudi Isiekwe, M. (2012). A cephalometric investigation of horizontal lip position in adult Nigerians. Journal of orthodontics, 39(3), 160-169. doi: 10.1179/1465312512Z.00000000026

[25] Jacobson, A., \& Jacobson, R. L. (2006). Radiographic Cephalometry: From Basics to 3-D Imaging (2nd edition). Quintessence Pub Co Limited, New Malden, Surrey, UK. ISBN10: 0867154616

[26] Joshi, M., Wu, L. P., Maharjan, S., \& Regmi, M. R. (2015). Sagittal lip positions in different skeletal malocclusions: a cephalometric analysis. Progress in orthodontics, 16(1), 8. doi: 10.1186/s40510-015-0077-x

[27] Moresca, R., Reis, S. A. B., Vigorito, J. W., \& Scanavini, M. A. (2010). Estudo comparativo cefalometrico-radiografico do padrao facial na ma-oclusao de Classe II, 1 de Angle, empregando as analises cefalometricas de Ricketts e Siriwat \& Jarabak. Jornal Brasileiro de Ortodontia \& Ortopedia Facial, 7(42), 520-525.

[28] Paranhos, L. R., Benedicto, E. N., Nunes, M. F., Kairalla, S. A., Furquim Siqueira, D., \& Cesar Torres, F. (2012). Correlation of different cephalometric measurements to define facial type. International Journal of Orthodontics, 23(1), 31. PMID: 22533026

[29] Perez, I. E., Chavez, A. K., \& Ponce, D. (2011). Cephalometric norms from posteroanterior Ricketts' cephalograms from Hispanic Americans Peruvian non adult patients. Acta Odontologica Latinoamericana, 24(3), 265-271. PMID: 22550820

[30] Perez, I., Chavez, A. K., \& Ponce, D. (2016). Applicability of the Ricketts' posteroanterior cephalometry for sex determination using logistic regression analysis in Hispano American Peruvians. Journal of forensic dental sciences, 8(2), 111. doi: 10.4103/0975-1475.186371

[31] Purmal, K., Alam, M. K., \& Zam Zam, N. M. (2013). Cephalometric norms of Malaysian adult Chinese. International Medical Journal, 20(1), 87-91.

[32] Ricketts, R. M. (1961). Cephalometric analysis and synthesis. The Angle Orthodontist, 31(3), 141-156.

[33] Silva, M. B. G. D., \& Sant'Anna, E. F. (2013). The evolution of cephalometric diagnosis in orthodontics. Dental press journal of orthodontics, 18(3), 63-71. PMID: 24094013

[34] Tikku, T., Khanna, R., Maurya, R. P., \&Ahmad, N. (2012). Role of buccal corridor in smile esthetics and its correlation with underlying skeletal and dental structures. Indian Journal of Dental Research, 23(2), 187. doi: 10.4103/0970-9290.100424 
[35] Tripathi, A. A., Tandon, R. P., \& Hantodkar, N. (2013). Facial divine proportions in attractive North Indian females: A photographic study. World Journal of Dentistry, 4(1), 41-46. doi: 10.5005/jp-journals-10015-1200

\section{РЕГРЕСІЙНІ МОДЕЛІ ІНДИВІДУАЛЬНИХ ЦЕФАЛОМЕТРИЧНИХ ПОКАЗНИКІВ, ЩО ВИКОРИСТОВУЮТЬСЯ В МЕТОДИЦІ R. M. RICKETTS Черниш А. B.}

Доведено, що при аналізі бокових телерентгенограм за різними методиками дистанції та кути мають свої нормативні показники які відрізняються для осіб різної етнічної, статевої та вікової приналежності. Тому для повноцінного використання в ортодонтії методу R. M. Ricketts необхідні подібні дослідження в Україні. Мета роботи - в юнаків і дівчат з нормальною оклюзією, наближеною до ортогнатичного прикусу, та гармонійним обличчям побудувати та провести аналіз регресійних моделей телерентгенографрічних показників, що використовуються в методиці R. M. Ricketts. Первинні бокові телерентгенограми 38 юнаків (віком від 17 до 21 року) та 55 дівчат (віком від 16 до 20 років) з нормальною оклюзією, наближеною до ортогнатичного прикусу, та гармонійним обличчям, отримані за допомогою пристрою Veraviewepocs 3D, Моріта (Японія), взяті з банку даних науково-дослідного центру Вінницького національного медичного університету ім. М. I. Пирогова. Цефралометричні вимірювання проводили згідно рекомендацій R. M. Ricketts. Усі показники були розділені на три групи: 1 - метричні характеристики черепа, які зазвичай не змінюються в ході хірургічного та ортодонтичного лікування; 2 зубощелепні показники, на визначення яких найбільш часто орієнтуються при виконанні ортодонтичних маніпуляцій пацієнтів дитячого, підліткового та юнацького віку, а також у осіб вже із сформованим кістковим скелетом коли ортодонтичні операції дозволяють змінювати ширину, довжину, кути та положення кісток верхньої і нижньої щелеп; 3 - показники які характеризують положення кожного окремого зуба по відношенню один до одного, до кісткових черепних структур та профрілю обличчя. Регресійні моделі індивідуальних телерентгенгографрічних показників, що використовуються в методиці R. M. Ricketts, побудовані за допомогою ліцензійного пакету "Statistica 6,0". Побудовані усі 2 достовірні моделі показників що увійшли до другої групи (відстані Go-CF i Xi-Pm) в залежності від показників першої групи (в юнаків $R^{2}=0,884$ i 0,928, а у дівчат - 0,735 і 0,719); а також в юнаків 7 із 8 можливих достовірних моделей $\left(R^{2}=\right.$ від 0,568 до 0,887) показників, що увійшли до третьої групи (величина відстаней 6u-6l, Overjet, Overbite, 6u-PTV, 1l-APog, 1u-APog i Xi-OcP) в залежності від показників першої та другої груп; та лише 5 моделей у дівчат (величина відстаней 6u-PTV, 11-APog, 1u-APog i Xi-OcP та величина кута Maх1-APog). При аналізі входження до регресійних моделей відповідних предикторів встановлено, що в юнаків серед телерентгенографічних показників першої групи, які увійшли до обох моделей показників другої групи входить відстань P-PTV, а у дівчат - передня довжина основи черепа N-CC та задня частина основи черепа Ar-Pt. Також встановлено, що в юнаків серед телерентгенографрічних показників першої і другої груп які увійшли до моделей показників третьої групи, найбільш часто входить величина відстані В-Роg (11,1\%); а у дівчат - величина відстані B-Pog (15,6\%) та величина кута DC-Xi-PM (9,4\%).

Ключові слова: регресійний аналіз, чефралометрія, аналіз R. M. Ricketts, юнакі та дівчата, ортогнатичний прикус.

\section{РЕГРЕССИОННЫЕ МОДЕЛИ ИНДИВИДУАЛЬНЫХ ЦЕФАЛОМЕТРИЧЕСКИХ ПОКАЗАТЕЛЕЙ, ИСПОЛЬЗУЕМЫХ В МЕТОДИКЕ R. M. RICKETTS \\ Черниш А. В.}

Доказано, что при анализе боковых телерентгенограмм по разным методикам дистанции и углы имеют свои нормативные показатели, которые отличаются для лиц разной этнической, половой и возрастной принадлежности. Поэтому для полноценного использования в ортодонтии метода R. M. Ricketts необходимы подобные исследования в Украине. Цель работы - у юношей и девушек с нормальной окклюзией, приближенной к ортогнатическому прикусу, и гармоничным лицом построить и провести анализ регрессионных моделей телерентгенографических показателей, используемых в методике R. M. Ricketts. Первичные боковые телерентгенограммы 38 юношей (в возрасте от 17 до 21 года) и 55 девушек (в возрасте om 16 до 20 лет) с нормальной окклюзией, приближенной к ортогнатическому прикусу, и гармоничным лицом, полученные $c$ помощью устройства Veraviewepocs 3D, Морита (Япония), взяты из банка данных научно-исследовательского центра Винницкого национального медицинского университета им. Н. И. Пирогова. Цефалометрические измерения проводили согласно рекомендациям R. M. Ricketts. Все показатели были разделены на три группы: 1 - метрические характеристики черепа, которые обычно не меняются в ходе хирургического и ортодонтического лечения; 2 - зубочелюстные показатели, на определение которых наиболее часто ориентируются при выполнении ортодонтических манипуляций пациентов детского, подросткового и юношеского возраста, а также у лиц уже со сформированным костным скелетом когда ортодонтические операции позволяют изменять ширину, длину, уәлы и положения костей верхней и нижней челюстей; 3 показатели, характеризующие положение каждого отдельного зуба по отношению друг к другу, к костным черепным структурам и профолю лица. Регрессионные модели индивидуальных телерентгенографических показателей, используемых в методике R. M. Ricketts, построены с помощью лицензионного пакета "Statistica 6,0". Построенные все 2 достоверные модели показателей вошедших во вторую группу (расстояния Go-CF и Xi-Pm) в зависимости от показателей первой группы (у юношей $R^{2}=0,884$ и 0,928, а у девушек - 0,735 и 0,719); а также у юношей 7 из 8 возможных достоверных моделей $\left(R^{2}=\right.$ om 0,568 до 0,887) показателей вошедшие в третью группу (величина расстояний 6u-6l, Overjet, Overbite, 6u-PTV, 1/APog, 1u-APog и Xi-OcP) в зависимости от показателей первой и второй групп; и только 5 моделей у девушек (величина расстояний 6u-PTV, 1l-APog, 1u-APog и Xi-OcP и величина угла Max1-APog). При анализе вхождения в регрессионные модели соответствующих предикторов установлено, что у юнощей среди телерентгенографических показателей первой группы вошедших в обе модели показателей второй группы входит расстояние P-PTV, а у девушек - передняя длина основания черепа N-CC и задняя часть основания черепа Ar- Pt. Также установлено, что у юношей среди телерентгенографических показателей первой и второй групп, вошедших в модели показателей третьей группы наиболее часто входит величина расстояния B-Pog (11,1\%); а у девушек - величина расстояния B-Pog $(15,6 \%)$ и величина уәла DC-Xi-PM $(9,4 \%)$.

Ключевые слова: регрессионный анализ, цефралометрия, анализ R. M. Ricketts, юноши и девушки, ортогнатический прикус. 